\title{
Examining of the Emotional Mood about Their Online Education of First-Year Students Beginning Their University Education with Distance Education Because of COVID-19
}

\author{
Halim Güner ${ }^{1}$ \\ ${ }^{1}$ Educational Sciences, Mus Alparslan University, Mus, Turkey \\ Correspondence: Halim Güner, Department of Educational Sciences, Education Faculty, Mus Alparslan \\ University, 49000 Mus, Turkey. E-mail: h.guner@alparslan.edu.tr \\ ORCID ID: https://orcid.org/0000-0003-1537-7655
}

Received: January 16, 2021

Accepted: February 1, $2021 \quad$ Online Published: February 13, 2021

doi:10.5539/hes.v11n1p148

URL: https://doi.org/10.5539/hes.v11n1p148

\begin{abstract}
The Covid-19 pandemic continues to be negatively effective in many areas of life. It has also affected the face-to-face education of 2020 fall semester. In Turkey, Students who have recently entered the university in 2020 started their undergraduate education with distance education like upper grade students. However, the fact that the first graders fell into the distance education system before experiencing university life and without knowing their teachers and friends created different emotional mood. The aim of this study is to analyze the emotional mood of students who have just get into university and have to start their undergraduate education with distance education. Exploratory sequential mixed method is used as a method of this study. Phenomenology method is used the first stage of the method and the survey method is used as the second stage of the method. A total of 18 fresh students (12 female and 6 male) in the departments of Faculty of Education and Faculty of Sport Sciences of Mus Alparslan University were the sample group of the qualitative stage. And 141 students (87 female and 54 male) were the sample of the quantitative stage. As a result of the qualitative analysis, the emotional moods of the students were grouped under four sub-themes: emotion of shock, unfamiliarity with the system, emotion of curiosity and anxiety for the future. First-year students stated that they experienced feelings of shock such as sadness and anxiety when they learned that they would start university with distance education instead of face-to-face education. The students stated that they wondered about the method of teaching the lessons, whether the lessons would be efficient, how the exams would take place, that they were unfamiliar with the system, and that they were worried about the future due to all these uncertainties. According to the analyzes obtained from the survey, it is understood from the answers that the 141 participant students experienced emotional states similar to the results obtained in qualitative findings at a rate of $90 \%$ and above. Only the rate of students experiencing an emotion of shock was $64.5 \%$ and the rate of experiencing future anxiety was $85.8 \%$. As a result, it was understood from the analyses that qualitative and quantitative results were parallel to each other.
\end{abstract}

Keywords: university, first year students, COVID-19, online education, emotional mood

\section{Introduction}

The COVID-19 pandemic, which caused a different and new process all over the world, has also guided academic studies in this process. Many journals have prioritized articles on the COVID-19 process or issued a special issue comprising COVID-19 researches. Many studies have been carried out for all educational levels in education. One of these levels is higher education. In the COVID-19 process, a significant number of studies have been conducted on the educational process of higher education (see Bao, 2020; Crawford et al., 2020; Murphy, 2020; Toquero, 2020). However, 781165 students (Higher Education Council, 2020) who are just get into universities in Turkey and waiting to begin face-to-face education will start distance education instead of face-to-face education and this event was encountered the first time. And it has been done no study on this situation, yet. Of course, it is guessed that students have many questions, concerns, fears and expectations in their minds. What students think and feelings about this new situation is serious curiosity and it should be examined.

There are many studies that approach the adaptation problems of students who start university with face-to-face 
education from different aspects (see Keller et al., 2008; Cooke et al., 2006; Horstmanshof \& Zimitat, 2007; McKenzie \& Schweitzer, 2001). In general, students experience the separation, transition, and adaptation stages in Tinto's (1993) theory. It is important for students to be separated from their families and their environment in a healthy way while starting the first grade, for their educational and social adaptation to be smooth (Mudhovozi, 2012; Thurber \& Walton, 2012, Archer et al., 1998). For this harmony to be successful, they must have a successful transition between the old and the new (Morton, Mergler, \& Boman, 2014; Provencher et al., 2009; Tieu \& Pancer, 2009). What is expected after a healthy separation and transition is the adaptation of the student to university life (Clinciu, 2013; Mudhovozi, 2012). This harmony is based on adaptation to academic (van Rooij, Jansen, \& van de Grift, 2018; Mudhovozi, 2012), to social life (Gray et al., 2013; Sevinç \& Gizir, 2014), to place of stay (Macaskill, 2013), to campus life (Jemal, 2012) and to the city. However, students who just get into one of the universities in Turkey in 2020 will experience no stage mentioned by Tinto (1993). Because they will start university with distance education, not face-to-face education due to Covid-19.

There are studies in the literature for students who study at universities that teach with distance education. In the studies, students who are educated with distance education have trouble with motivation (Nehme, 2010; Hart, 2012; Kim et al., 2004; Pollanen, 2007), satisfaction (Horvat, Krsmanovic \& Djuric, 2012; Varner, 2013), and competence (Byungura et al., 2018; Balderas et al., 2015). Students may have motivation problems in online education and therefore the teachers should pay attention to this point. The teachers play an active role in explaining the importance of the lesson at the beginning, explaining the target gains, and providing support in the places where the student is incompetent (Nehme, 2010). Similar to motivation, students' satisfaction with distance education is also a factor affecting their success. For this reason, online education should be well designed, support with orientation training, and appropriate online learning environments should be created (Horvat, Krsmanovic, \& Djuric, 2012). Apart from motivation and satisfaction, incompetence of technology is observed especially among students who have just started university. Apart from some basic usage of technology, students cannot use some high-tech programs and tools. (Byungura et al., 2018). Of course, such a situation affects the efficiency of the student.

Some other studies related to distance and face-to-face education, whose samples are the first-year university students, are about the intertwining of two education types (blended education) (Ellis \& Bliuc, 2016; Stone, 2005; Chapman, 2019; Pillay and Gerrard, 2011). Although students cannot gain a high level of efficiency from new and innovative inquiry-based training for university students in blended contexts, it is an effective method of teaching for teachers (Ellis \& Bliuc, 2016). In another study, it was determined that students said they benefited from technology-supported education (Stone, 2005). Chapman (2019) stated that an education supported by a mobile phone would be more effective and that while the student continued to benefit from the mobile phone and questions from students could be addressed at the same time. In summary, when blended education is carefully planned and implemented, it is seen that it is more effective in student achievement and provides great advantages to both students and teachers (Yigit et al., 2014).

Despite all these studies on first-year university students, there is a need for studies on new situations in education because of the COVID-19 pandemic. Such a new situation in Turkey is first-year university students unable to start their undergraduate education with face-to-face education. There are no answers to the questions of what are the worries, problems, feelings, and expectations of these students who will start their university with distance education. In all academic fields, especially those experiencing rapid growth, there is a need to analyze events with an overview and learn how to fill knowledge gaps (Creswell, 2003; Webster \& Watson, 2002). This idea explains the reason why first-year students starting university with distance education are the subject of this study. Specifically, the purpose of this article is to examine the mood of first-year university students who had to start their university education with distance education due to the COVID-19 pandemic.

\section{Method}

\subsection{Model}

In this research, one of the mixed methods, the exploratory sequential mixed method, was used. In the exploratory sequential mixed method, qualitative method research is carried out first, and then a quantitative method is applied. This design is used in order to question how much generalizations of the findings got from the qualitative data we can make in a larger sample (Creswell, 2014, p.226).

In this study, the qualitative method, which is the first step of the mixed method, was designed as phenomenology research. Phenomenology research focuses on how individuals understand the phenomena they live and experience, what understandings they attribute to them, what they feel, how they define them, and what meaning they share with other people (Patton, 2002, p.104). 
The second stage of the mixed method was the scanning model, one of the quantitative models decided by the application of closed-ended questions created from qualitative findings. Scanning is a method of showing a situation as it is without trying to affect it (Karasar, 2016, p.109).

\subsection{Sample Group}

The sample of this study comprises the first-year students who just be students in Mus Alparslan University Faculty of Education in the departments of Turkish, Science, Guidance and Psychological Counseling and Social Studies and Mus Alparslan University Faculty of Sports Sciences in the Department of Exercise and Sports for the Disabled in 2020.

The study group of the phenomenology phase comprised 18 students who voluntarily took part in the departments of the sample. The gender distribution of 18 students is as 12 female and 6 male students.

The sample of the second stage, the quantitative stage, comprised 141 students who volunteered from selected departments. The sample of this study is an easily accessible sampling method, since the people that the researcher can easily reach form the sample (Creswell, 2014). 141 students comprising the quantitative sample were distributed as 87 female (61.7\%) and 54 male (38.3\%) students.

\subsection{Data Collection Tool}

As a data collection tool, two separate tools were used for qualitative data collection and quantitative data collection. A structured interview form was used as a qualitative data collection tool. The interview form was structured and comprised an open-ended question. The open-ended interview question is about the students' writing their feelings about starting formal education with distance education. Because of the impossibilities, the data were collected not by interviewing face to face, but by the students writing and sending their thoughts on the question on A4 paper. Data were collected from 18 students in this way. When necessary, drilling questions were asked to the students to clarify the answers.

As a quantitative data collection tool, the questionnaire form created from the results got from qualitative data analysis was used. The questionnaire included 10 questions, including a demographic question about gender. The questions were delivered to 221 students in the form of an online questionnaire, and 141 people voluntarily filled it.

\subsection{Data Analysis}

Students were asked to describe the emotions they experienced due to starting university with distance education. For this reason, the themes emerging in the coding were handled as sub-themes under the theme of emotions. The findings obtained from the students were analyzed by content analysis, which is a qualitative data analysis method. The content analysis includes identifying, coding, categorizing, and labeling the patterns in the data (Patton, 2014, p. 483). Firstly, the data is encoded. After the coding process was completed, sub-themes were created by bringing together the codes corresponding to similar meanings. As a result of the themes, four sub-themes were formed as "Emotion of Shock", "Unfamiliarity with the System", "Emotion of Curiosity" and "Future Anxiety". After determining the appropriate quotations for the themes, the writing phase started. Descriptive letters and numbers such as $\mathrm{S} 1, \mathrm{~S} 2, \mathrm{~S} 3, \mathrm{~S} 4, \ldots$ that show the number of participants was added at the end of the quotations ( $\mathrm{S} 1$ = first student, $\mathrm{S} 2$ = second student).

SPSS package program was used in the analysis of quantitative methods. The frequency and percentage values of the data collected through the questionnaire were examined. Qualitative and quantitative analysis results are presented as blended in the findings section.

\section{Results}

As a result of the analysis of the collected data, the emotions experienced by the students because of starting their undergraduate education with online education rather than face-to-face were gathered under four sub-themes. These sub-themes under the theme of emotions are emotion of shock, unfamiliarity with the system, emotion of curiosity, and future anxiety.

\subsection{Emotion of Shock}

Participants expressed their emotions that after entitle to be fresh students of the university, they experienced a shock with the debrief that they will begin their education remotely. One student expressed his feelings of anxiety and worry, which many students have, as "worry, this word means anxiety in me. Now I am in anxiety (S17)" and another student seems to have described it by saying "I am definitely anxious (S16)". One student expressed her emotional shock by saying, "I am sorry, I did not have to imagine like that (S11)". She continued, "We had a hard time. I am totally excited to begin university for the first time, I hope that I have worked hard to 
experience all these exciting feelings, I hope this situation will come as soon as possible and I hope those good days will come (S11)". The feeling of shock found its expression in another student as being in bitter feelings. She stated she was shocked by not being able to enter the university campus, not meeting new friends, not having a new social life and she expressed her emotions by saying, "I am in bitter feelings because we cannot attend classes at school because of reasons beyond our control (S6)". The emotion of shock showed the highest degree in a student's word "disaster (S1)". The hopes of the students about having face-to-face education had severe destruction with the saying "attending online classes without seeing the university environment is disastrous for me (S1)".

A question about whether the students experienced a shock when they first learned they would begin their undergraduate education with a distance education was asked as a survey question. The frequency and percentage values of the answers given by the students are given in table 1.

Table 1. Frequency and Percentage Values of the Emotion of Shock Experienced by Students when They are First Heard that Their Undergraduate Education will be with Distance Education

\begin{tabular}{lllll}
\hline & No Shock & Some-Moderately Shock & Very-Very Much Shock & Total \\
\hline Frequency & 50 & 63 & 28 & 141 \\
Percentage & 35,5 & 44,7 & 19,9 & 100 \\
\hline
\end{tabular}

Looking at the answers given by the students, $35.5 \%$ of the participants stated they did not feel any shock when they heard the distance education information. The remaining $64.5 \%$ of the participants stated they experienced some-moderately $(44.7 \%)$ and very-very much $(19.9 \%)$ perceptions of shock. It can be said that the students generally experience the feeling of shock moderately or do not experience this feeling.

When students who were shocked were asked to describe their emotion of shock, they described their feelings with one or more emotions such as bitterness, sadness, anxiety and sadness, panic and anxiety, and anxiety. When the frequency values of the words were examined, the word Sadness was written 43 times, the word Anxiety 29 times, the word Bitterness 22 times, the word Confused 11 times, and the word Panic 10 times by the participant students. As can be understood from the frequency values of the words, it can be said that students generally experience sadness, anxiety, and bitterness as a sense of shock.

\subsection{Unfamiliarity with the System}

After the shock experienced by the students who could not begin to university with face-to-face education like upper-grade students, it was maybe the first time for them to hear concepts such as "virtual classroom", "google classroom", "zoom", "class code", "synchronous", "asynchronous", "google meet". They tried to solve the distance education systems they met for the first time with their own efforts and get used to the system. One student put this difficult process into sentences effectively; "I can say that it was one of the terrible memories I will never forget in my life. When I learned the university would not open and it would be online, I was worried and terrified. Because I was the first university student in my family and I had no idea. When I talked to university students about what to do for online education, they obviously increased my fears. The lessons started remotely and I tried to learn and manage problems on my own, but I just couldn't. I even cried (S14)".

Although the new generation of students is familiar with smartphone technology and the virtual world, it cannot be said that they are familiar with the internet programs used in online education. Generally, no matter how simple a method that people first hear, one can experience fear and anxiety. One student's statement, "I did not know how the process worked because I had never received distance education before, and this worried me more (S12)", expressed the anxiety and unfamiliarity experienced by many students. Another student expressed the situation as "it is so complex for me (S17)". The reason for the complexity was cited as the inability to adapt to and access to distance education; "Even in normal education, there is a difficult adaptation period, what a difficult adaptation process for distance education. Yes, our lessons have started, but this is very difficult for me, there are impossibilities. The biggest problem is that I have a digital access problem (S17)".

A survey question was asked to the students who recently entered the university and started their formal education with distance education, about how well they know the concepts related to distance education. The frequency and percentage values of the answers given by the students are given in Table 2 . 
Table 2. Frequency and Percentage Values of Students' Familiarity with Distance Education Concepts

\begin{tabular}{lllll}
\hline & I knew it all & There were concepts I knew and I didn't know & I just heard-learned it all & Total \\
\hline Frequency & 7 & 72 & 62 & 141 \\
Percentage & 5 & 51 & 44 & 100 \\
\hline
\end{tabular}

According to the table, it is seen that all students, except $5 \%$ of the participants, are not familiar with the concepts for distance education (virtual classroom, classroom, classroom code, meet, zoom, etc.). $51 \%$ of the students stated that they knew only some concepts related to distance education, and $44 \%$ stated that the first time heard or learned these concepts.

A questionnaire was asked to the students about how the process of learning these new concepts and getting used to the system was passed. The frequency and percentage values of the answers given by the students are shown in Table 3.

Table 3. Frequency and Percentage Values of Students Getting Used to the Distance Education System at the beginning of the Term

\begin{tabular}{llllll}
\hline & $\begin{array}{l}\text { I was already used } \\
\text { to the system }\end{array}$ & $\begin{array}{l}\text { It was easy for me } \\
\text { to get used to it }\end{array}$ & $\begin{array}{l}\text { I had a little (moderate) } \\
\text { difficulty adjusting }\end{array}$ & $\begin{array}{l}\text { I had a hard time } \\
\text { getting used to }\end{array}$ & Total \\
\hline Frequency & 3 & 34 & 63 & 41 & 141 \\
Percentage & 2,1 & 24,1 & 44,7 & 29,1 & 100 \\
\hline
\end{tabular}

According to the frequency and percentage values are given in the table, only $2.1 \%$ of the participants stated they are used to the system. $24.1 \%$ of the students stated it was easy to get used to the distance education system, $44.4 \%$ had a little-moderate difficulty in getting used to the system, and $29.1 \%$ had a hard time getting used to the system. We can infer from the frequency and percentage values that students have difficulty adjusting to the system.

\subsection{Emotion of Curiosity}

The third sub-theme is determined as the emotion of curiosity theme. After being shocked and having problems being familiar with the system, the students stated they were curious about how the lessons would be, the level of efficiency of online lessons, and how the exams will take. A student expressed his curiosity by asking repeated questions; "It is an alarming situation that schools do not open, as the face-to-face education is more practical and familiar. My major concern is how the process will work. For example, will the online lessons be alive? How will there be cases of absence? How are mid-term and finals exams planned? If homework will be done, will this system be fair? I am curious about what will happen. I talked to my friends about this issue, they are also worried (S8)". Another student said he had questions in his mind, and one of these questions was the question of how the lessons will be. She stated that "I had a lot of questions in my head waiting to be answered; such as the university environment, my teachers, my friends, lessons, exams (S12)". She continued and said that "Because it was my first year, there was excessive anxiety, stress, and excitement. But I know I can overcome this. When I received the news that we would have our lessons remotely because of the pandemic, I was had questions such as how our lessons will be taught, how will the exams be, will online lessons be useful? (S12)".

The curiosity of the students about how to handle distance education lessons was directed to the students as a survey question. The frequency and percentage values of the answers given by the students are given in table 4 below.

Table 4. Frequency and Percentage Values of Students' Curious about How Online Lessons will be Processed

\begin{tabular}{lllll}
\hline & I was not curious & I was a little-moderately curious & I was very curious & Total \\
\hline Frequency & 11 & 47 & 83 & 141 \\
Percentage & 7,8 & 33,3 & 58,9 & 100 \\
\hline
\end{tabular}

It is understood from the table that 141 students who answered the questionnaire, except $7.8 \%$, are curious about how the teachers will teach their lessons with distance education and their methods. 33.3\% of the participant students stated their level of curiosity as slightly-moderately, and 58.9\% stated that they were too-too much.

The curiosity of some students about how the online lessons will be taught has been expressed with the word efficiency. Some students expressed their curiosity about whether or not the lessons would be efficient in 
different ways. A student expressed this curiosity such that "In this case, how long will education continue like this? We have just started university, how our applied courses will be, how much efficiency we can get from online courses (S1)" and stated that this situation frightened her with the phrase "these scares me very much (S1)". Another student wondered if the lessons would be inefficient, "I'm worried I will not be able to fully comprehend the subjects (S7)" and another student with close sentences stated that "I'm afraid of not being able to understand the lessons because the courses are online and our grades will be low (S9)". Another student expressed his curiosity about whether or not the lessons were efficient, with the question marks in his mind as "How useful it would be if we saw the lessons with distance education and whether I would get efficiency from the lessons was always a question mark in my mind (S12)".

The students stated in the qualitative research phase that they were curious about how the lessons would be taught, as well as how efficient the lessons to be taught with distance education would be. In order to determine the frequency and percentage values of the students' thoughts about efficiency, their opinions about whether the online lessons will be efficient were asked as a survey question. The frequency and percentage values of the answers are shown in Table 5.

Table 5. Frequency and Percentage Values of Students' Curious about the Efficiency of Distance Education Lessons

\begin{tabular}{lllll}
\hline & I was not curious & I was a little-moderately curious & I was very curious & Total \\
\hline Frequency & 9 & 41 & 91 & 141 \\
Percentage & 6,4 & 29,1 & 64,5 & 100 \\
\hline
\end{tabular}

Similar to the response rates given to the question of how the lessons will be taught, only $6.4 \%$ of the students stated they do not wonder whether the lessons to be taught with distance education will be efficient. $29.1 \%$ of the students stated they wondered whether the lesson would be efficient as a little-medium and $64.5 \%$ of the students wondered very much. In this case, it can be said that $93.6 \%$ of the students are curious about the efficiency of the lessons they will receive with distance education.

After the questions of how the lessons will be taught and whether they will be efficient, the other thing that students wondered most was the exams. The students frequently expressed their fears about how the exams would be and getting low grades. One of the students expressed his curiosity about the exam and his fears of failure and said, "I am concerned about the exams. Just when we say that we survived the university exam, we do not want to fail in the midterm and final exams (S10)". Sentences such as "How the teacher's exam style will be (S17), the uncertainty about how the exams will be conducted (S18), I am worried that I will not perform well in the exams (S16), I am afraid that I will do badly in the exams (S5)" reflect the students' anxiety and curiosity about exams.

It was obtained from the qualitative data that the students were curious about how to conduct the exams of the lessons to be given by distance education, that is, the evaluation system. This data was directed to the students as a survey question, and the frequency and percentage values of their answers are given in Table 6.

Table 6. Frequency and Percentage Values of Students' Curiosity about the Exams of the Lessons to be Taught with Distance Education.

\begin{tabular}{lllll}
\hline & I was not curious & I was a little-moderately curious & I was very curious & Total \\
\hline Frequency & 7 & 30 & 104 & 141 \\
Percentage & 5 & 21,2 & 73,8 & 100 \\
\hline
\end{tabular}

$5 \%$ of the participants stated they do not wonder how the exams of the online lessons. The remaining 95\% stated that they were curious about the exam system of the online lessons. $21.2 \%$ of the group who said they were curious stated that they were wonder little-moderately, and $73.8 \%$ stated that they were very curious.

\subsection{Future Anxiety}

Future anxiety developed in students as a result of their worries about the efficiency of their lessons and fear of failing the exams. It is observed in their sentences they think they will be incompetent in their work as a result of their inefficient learning from online lessons. For example, a student said, "I realized that after taking the lessons of the first week, I did not understand anything and could not focus. Because the system was constantly 
collapsing, we were expelled from the lessons by the system after taking the classes (S12)". Later on, the student said that "When the situations were like this, my worries were replaced by the anxiety of the future and my fears about the future started (S12)". The student expressed these fears as follows; "I asked myself what kind of teacher I would be if I continued with distance education and graduated without understanding the lessons and without efficiency. How can we be the hope of the future if these days are not bright? (S12)". Another student expressed his future anxiety with similar words and said that "what we all want is a good future and this worries me too much (S1)". She stated problems of impossibilities and said that "the student wants opportunities, wants to learn, and want to have better jobs. We should also consider students who have the means or who do not. Everyone's possibilities are not equal, unfortunately (S1)".

Another student, who is worried about the future, said she wants a quality education and she expressed her thoughts that "Of course I am worried about education. I want to get a quality education like everyone else. Face-to-face training is absolutely indisputable, and should be started as soon as possible (S4)". Another student stated he was worried about will see the effects of inefficient distance education in business life. He explained this problem, which he may face when he starts in business life with these sentences; "Since we direct our future, it will cause us to start with incomplete information in our business life. This situation also worries me (S3)". Another student who combined exam anxiety and future anxiety said, "There is future anxiety. I'm afraid if I couldn't pass the class. Or I am afraid that I will fail (S2)". She specified he was afraid of the negative reflection of his failure in the exam on his future. Finally, another student expressed his future anxiety in the form of addressing and demanding authorities; "The individual situations of the students should be taken into consideration, and even one by one should be called and asked about communication networks (computer, tablet, phone, internet access, etc.). Because there is no compensation for time. The living conditions and opportunities of individuals cannot be the same. Education is a precious element, and it flows in equal to time, so I expect the sensitivity (S17)".

In qualitative research, it was revealed that students experienced an emotion of anxiety about their future after their feelings of shock, unfamiliarity, and curiosity during this process. The future anxiety experienced by the students was asked as a survey question. The frequency and percentage values of the answers given by the students are given in Table 7.

Table 7. Frequency and Percentage Values of Students' Future Anxiety because of Distance Education

\begin{tabular}{lllll}
\hline & None & Some-Moderately & Very Much & Total \\
\hline Frequency & 20 & 54 & 67 & 141 \\
Percentage & 14,2 & 38,3 & 47,5 & 100 \\
\hline
\end{tabular}

According to the data in the table, $85.8 \%$ of the students stated they had a concern for the future and for would being incompetent in their future professions because of the inefficiency and ineffectiveness of the distance education lessons. Students stated that their future anxiety levels were $38.3 \%$ little-moderately and $47.5 \%$ very much. $14.2 \%$ of the participant group stated they do not have any future concerns.

One result of the qualitative research is that the students stated one reason for their fears about the future was that they haven't enough opportunities (internet, internet quota, computer, smartphone, teacher, etc) and therefore they were concerned they would fall behind in education. This situation was directed to the students as a questionnaire question. The answers given by the students are shown in table 8 .

Table 8. Frequency and Percentage Values of Students Having Problems in Distance Education

\begin{tabular}{lllll}
\hline & None & Yes, Sometimes & Yes, Often-Constantly & Total \\
\hline Frequency & 23 & 77 & 41 & 141 \\
Percentage & 16,3 & 54,6 & 29,1 & 100 \\
\hline
\end{tabular}

According to Table $8,54.6 \%$ of the students, representing the majority of students, stated that they sometimes experience various problems in their distance education. $29.1 \%$ of the participants stated that they constantly or often experience problems, and $16.3 \%$ of them stated they do not have any problems in distance education.

\section{Discussion and Conclusion}

Unlike their peers in the previous years, students who will be students in a department at the university and have 
an undergraduate education in the 2020-2021 academic year started their fall semester with online learning. When the emotions of the students who started their education with such a process because of the COVID-19 virus were examined, their emotions were categorized under four sub-themes. Sub-themes were determined as emotion of shock, unfamiliarity to the system, emotion of curiosity, and future anxiety.

As a result of the analysis of both qualitative and quantitative data, students experience an emotional tension that can be called shock in different emotions when they learn they will have their education remotely. Explaining their feelings in different words, the students stated that they mostly felt sadness, anxiety, and bitterness. Some students stated that they already expected that the education would be remote and therefore they did not experience any shock. It was also determined that the students who did not experience shock were $35.5 \%$ of the students taking part in the survey. Studies on the shocks experienced by first-year university students show these shocks are generally experienced because of encountering different cultures (Cushman, 2007; Cameron \& Kirkman, 2010). The shock feelings of the students detected in this study are mentioned for the first time in the literature because this event is the first time encountered.

Students emphasized that when they started distance education, they heard first time some concepts about online education. We can say that the process of getting used to these concepts from a student's saying "I even cried (S14)" is a very difficult process for some students. From the quantitative data, it was determined that the rate of those who heard the concepts such as "virtual classroom, classroom, classroom code, meet, zoom, etc." about distance education for the first time was $95 \%$. It is understood from these rates that most of the students are not familiar with the concepts of distance education, even though they have smartphones. Unfamiliarity with these concepts may cause difficulties in getting used to the distance education system. In the qualitative data, the situation of the students who stated that it was difficult to get used to the system was found in the quantitative sample group as $73.8 \%$. In studies on distance education, it has been determined that both students and lecturers have technological incompetences (Khan \& Khan, 2019; Ocak, 2011). Apart from these, there were students who stated that they are already used to the system or that the adaptation process was easy in the qualitative and quantitative samples.

It has been observed that students who are new at the university after the shock and feeling of familiarity with the system are curious about how the courses will be taught, whether the courses to be taught with distance education will be efficient and how the exams will be held. In the qualitative data, statements about how the courses will be taught with distance education were expressed by the students. The quantitative rate of curiosity about how the lessons will be taught was $92.2 \%$. It is understood from this rate and qualitative data that students were curious about this issue.

Another issue that students are curious about is whether the lessons to be taught in distance education will be efficient. The students expressed their concerns and curiosity about the inefficient of distance education lessons in the qualitative study. These expressions took place at a rate of $93.6 \%$ in the quantitative study. In the quantitative study, it is understood that students had a different level of curiosity about the efficiency of the lessons, except for $6.4 \%$ of the participants. In studies conducted on whether students see online education as efficient or not, it has been found that students generally do not see online education as efficient (Adnan \& Anwar, 2020; Orhan \& Beyhan, 2020).

Another issue that is most curious about students who are new to university is how the exams will be, that is, how the evaluation system will be. It is understood from the qualitative data that students were curious about issues such as how to conduct exams online, whether a problem will be encountered, and how the assessment style will be. This situation was analyzed at a high rate of $95 \%$ in quantitative data. Thus, it is understood that the exam system and style are a matter of curiosity for many students.

The worries and fears experienced by students who have just started university in the COVID-19 process they pass manifest themselves as anxiety for the future. Students who went through an abnormal process stated they could not have a good education, that whether they would have any problems in their profession in the future with this education, and that they experienced a sense of future anxiety because of the inefficient education. Future anxiety, which is expressed as incomplete information, not passing class, failing, graduating with insufficient knowledge, fear of what kind of teacher s/he will be, manifests itself in $85.8 \%$ of the quantitative data. $47.5 \%$ of this rate stated that they experienced the feeling of future anxiety as very much. From these rates and qualitative data, it can be said that most of the students have anxiety because of uncertainty. In the literature, it is emphasized that worrying about uncertainty and intolerance of uncertainty is effective in the development of anxiety and symptoms related to anxiety (Chen, Yao, \& Qian, 2018). This emotion of anxiety has shown its most concrete form in the profession and in unqualified graduation. Zaleski (1996) defines future anxiety as distant 
future anxiety, uncertainty, fear, and anxiety of negative changes.

In the qualitative data, it was observed that students frequently talked about fear of experiencing problems because of technological problems and impossibilities in the sub-themes of the emotion of shock, feeling of unfamiliarity to the system, emotion of curiosity, and future anxiety. On the one hand, another problem is that students worry about falling behind their peers because of technical difficulties (individual and/or systemic). When the size of this problem was investigated quantitatively, $54.6 \%$ stated that they sometimes experience various problems in their distance education, $29.1 \%$ frequently experienced problems in their distance education, and $16.3 \%$ stated that they did not experience any problems in distance education. In general, it is understood that students experience small or big problems sometimes and always-frequently due to technical difficulties and troubles in distance education. It can be assumed that the rates of these problems are substantial and this may affect the students' future. Similarly, it is one finding in the literature that distance education students experience technology-related problems and troubles (see Alexander, Truell, \& Zhao, 2012; Arthur-Nyarko, Agyei, \& Armah, 2020).

As a result, it can be said that students who enter the university during the abnormal periods because of the COVID-19 epidemic started the 2020 fall semester with some abnormal emotions compared to other university students. It was observed that these students could not experience the excitement of starting the university face-to-face education like other undergraduate students, and instead of this excitement, they experienced sadness, anxiety, and bitterness that could be called shock emotions. It is understood that these students, unlike other undergraduate students, have a problem getting used to the system before their teachers and friends. In addition, it is understood from both qualitative and quantitative data that these students are more curious about how things will go about many issues and that they are worried about the future because of all these abnormal processes.

\section{Suggestions}

The fact that the students who have recently entered the university in 2020 start their classes with distance education has been a result of the COVID-19 pandemic. In the light of the results got from this study, it is recommended that the enlighten training or guides are prepared in advance and shared with the relevant people so that students do not experience uncertain situations in abnormal processes similar to this process. Thus, panic situations and negative emotions of the students will be prevented to some extent.

Where preparations for abnormal situations are not good enough, it is a natural result to have risky situations. For this reason, it is recommended to calculate the risks that may arise in advance and take precautions, share this situation with the students and ensure that they are emotionally relieved.

In order to prevent unjust losses caused by students because of impossibility or external factors, it is recommended to officially ensure that unjust losses are prevented and compensated, and students should be informed in detail.

Finally, researchers are recommended to repeat the quantitative part of this study by collecting data from a wider audience. In addition, it is recommended to determine student victimization at the end of the semester with new researches.

\section{Limitations}

In this study, making the quantitative method with 141 people can be seen as a limitation. In order for the generalization of quantitative methods to be healthy, the sample size should be at a sufficient level. Therefore, this situation is considered being a limitation in terms of the objectivity of the research.

The fact that the participants are from only one university is also a limitation to generalize the results of the research. Re-doing the research by collecting data from different universities may contribute to the generalization of the results more objectively.

Finally, it is seen as a limitation that the students comprise students who take the researcher's course. This situation may have had a slight effect on the answers of the students.

\section{Funding}

This study wasn't funded by any persons or organizations.

\section{References}

Adnan, M., \& Anwar, K. (2020). Online Learning amid the COVID-19 Pandemic: Students' Perspectives. Online Submission, 2(1), 45-51. https://doi.org/10.33902/JPSP.2020261309 
Alexander, M. W., Truell, A. D., \& Zhao, J. J. (2012). Expected advantages and disadvantages of onlıne learning: Perceptions from college students who have not taken online courses. Issues in Information Systems, 13(2), 193-200.

Archer, J., Ireland, J., Amos, S. L., Broad, H., \& Currid, L. (1998). Derivation of a homesickness scale. British Journal of Psychology, 89(2), 205-221. https://doi.org/10.1111/j.2044-8295.1998.tb02681.x

Arthur-Nyarko, E., Agyei, D. D., \& Armah, J. K. (2020). Digitizing distance learning materials: Measuring students' readiness and intended challenges. Education and Information Technologies, 1-16. https://doi.org/10.1007/s10639-019-10060-y

Balderas, A., Dodero, J. M., Palomo-Duarte, M., \& Ruiz-Rube, I. (2015). A domain specific language for online learning competence assessments. International Journal of Engineering Education, 31(3), 851-862.

Bao, W. (2020). COVID-19 and online teaching in higher education: A case study of Peking University. Human Behavior and Emerging Technologies, 2(2), 113-115. https://doi.org/10.1002/hbe2.191

Byungura, J. C., Hansson, H., Muparasi, M., \& Ruhinda, B. (2018). Familiarity with Technology among First-Year Students in Rwandan Tertiary Education. Electronic Journal of e-Learning, 16(1), 30-45.

Cameron, H., \& Kirkman, C. (2010). Managing culture shock for first year international students entering Australian universities. In First Year in Higher Education Conference, University of Queensland, St Lucia, Australia.

Chapman, J. (2019). Blended learning and the motivation to learn the English language: A mixed methods study based on first-year university students in Japan. Doctoral dissertation. University of Liverpool. Retrieved from https://livrepository.liverpool.ac.uk/3056961/1/H00023155_Feb2019.pdf

Chen, S., Yao, N., \& Qian, M. (2018). The influence of uncertainty and intolerance of uncertainty on anxiety. Journal of behavior therapy and experimental psychiatry, 61, 60-65. https://doi.org/10.1016/j.jbtep.2018.06.005

Clinciu, A. I. (2013). Adaptation and stress for the first year university students. Procedia-Social and Behavioral Sciences, 78, 718-722. https://doi.org/10.1016/j.sbspro.2013.04.382

Cooke, R., Bewick, B. M., Barkham, M., Bradley, M., \& Audin, K. (2006). Measuring, monitoring and managing the psychological well-being of first year university students. British Journal of Guidance \& Counselling, 34(4), 505-517. https://doi.org/10.1080/03069880600942624

Crawford, J., Butler-Henderson, K., Rudolph, J., Malkawi, B., Glowatz, M., Burton, R., \& Lam, S. (2020). COVID-19: 20 countries' higher education intra-period digital pedagogy responses. Journal of Applied Learning \& Teaching, 3(1), 1-20. https://doi.org/10.37074/jalt.2020.3.1.7

Creswell, J. W. (2003). Research design: Qualitative, quantitative, and mixed methods approaches (2nd ed.). Thousand Oaks, CA: Sage Publications.

Creswell, J. W. (2014). Research Design: Qualitative, Quantitative, and Mixed Methods Approaches (4th ed.). Sage Publications.

Cushman, K. (2007). Facing the culture shock of college. Educational Leadership, 64(7), 44. https://doi.org/10.22401/JNUS.10.1.03

Ellis, R. A., \& Bliuc, A. M. (2016). An exploration into first-year university students' approaches to inquiry and online learning technologies in blended environments. British Journal of Educational Technology, 47(5), 970-980. https://doi.org/10.1111/bjet.12385

Gray, R., Vitak, J., Easton, E. W., \& Ellison, N. B. (2013). Examining social adjustment to college in the age of social media: Factors influencing successful transitions and persistence. Computers \& Education, 67, 193-207. https://doi.org/10.1016/j.compedu.2013.02.021

Hart, C. (2012). Factors associated with student persistence in an online program of study: A review of the literature. Journal of Interactive Online Learning, 11(1).

Higher Education Council (Yükseköğretim Kurumu (YOK)). (2020). Yükseköğretim Kurulu 2020 Yllı Yüksekögretim Kurumları Sinavı Yerleştirme Sonuçları Raporu. Retrieved from https://basin.yok.gov.tr/AciklamaBelgeleri/2020/24-yks-yerlestirme-sonuclari-raporu-2020.pdf

Horstmanshof, L., \& Zimitat, C. (2007). Future time orientation predicts academic engagement among first-year university students. British Journal of Educational Psychology, 77(3), 703-718. 
https://doi.org/10.1348/000709906X160778

Horvat, A., Krsmanovic, M., \& Djuric, M. (2012). Differences in students' satisfaction with distance learning studies. International Journal of Social, Behavioral, Educational, Economic, Business and Industrial Engineering, 6(6), 1412-1415.

Jemal, J. (2012). Assessing major adjustment problems of freshman students in Jimma University. Ethiopian Journal of Education and Sciences, 7(2), 1-14.

Karasar, N. (2016). Bilimsel Araştırma Yöntemi: Kavramlar, Illkeler, Teknikler (30. Basım). Ankara: Nobel Yayın Dağıtım.

Keller, S., Maddock, J. E., Hannöver, W., Thyrian, J. R., \& Basler, H. D. (2008). Multiple health risk behaviors in German first year university students. Preventive medicine, 46(3), 189-195. https://doi.org/10.1016/j.ypmed.2007.09.008

Khan, S., \& Khan, R. A. (2019). Online assessments: exploring perspectives of university students. Education and Information Technologies, 24, 661-677. https://doi.org/10.1007/s10639-018-9797-0

Kim, K. J., Lu, X., Lee, S. H., Bonk, C. J., Magjuka, R. J., Liu, S., ... Wise, A. (2004). Online facilitation and motivation in online MBA courses. Association for Educational Communications and Technology. Retrieved from https://files.eric.ed.gov/fulltext/ED485054.pdf

Macaskill, A., \& Denovan, A. (2013). Developing autonomous learning in first year university students using perspectives from positive psychology. Studies in Higher Education, 38(1), 124-142. https://doi.org/10.1080/03075079.2011.566325

McKenzie, K., \& Schweitzer, R. (2001). Who succeeds at university? Factors predicting academic performance in first year Australian university students. Higher education research \& development, 20(1), 21-33. https://doi.org/10.1080/07924360120043621

Morton, S., Mergler, A., \& Boman, P. (2014). Managing the transition: The role of optimism and self-efficacy for first-year Australian university students. Journal of Psychologists and Counsellors in Schools, 24(1), 90-108. https://doi.org/10.1017/jgc.2013.29

Mudhovozi, P. (2012). Social and academic adjustment of first-year university students. Journal of Social Sciences, 33(2), 251-259. https://doi.org/10.1080/09718923.2012.11893103

Murphy, M. P. (2020). COVID-19 and emergency eLearning: Consequences of the securitization of higher education for post-pandemic pedagogy. Contemporary Security Policy, 41(3), 1-14. https://doi.org/10.1080/13523260.2020.1761749

Nehme, M. (2010). E-learning and students' motivation. Legal Education Review, 20(1).

Ocak, M. A. (2011). Why are faculty members not teaching blended courses? Insights from faculty members. Computers \& Education, 56(3), 689-699. https://doi.org/10.1016/j.compedu.2010.10.011

Orhan, G., \& Beyhan, Ö. (2020). Teachers' perceptions and teaching experiences on distance education through synchronous video conferencing during covid-19 pandemic. Social Sciences and Education Research Review, 7(1), 8 .

Patton, M. Q. (2002). Qualitative Evaluation and Research Methods (3rd ed.). Londan: Sage Pub.

Patton, M. Q. (2014). Nitel Araştırma ve Değerlendirme Yöntemleri. Çeviri Editörleri: Mesut Bütün ve Selçuk Beşir Demir. Ankara: Pegem Akademi.

Pillay, R., \& Gerrard, P. (2011). Implementing a "blended learning approach" in a social work course: The perceptions of first-year students at a South African university. Social Work/Maatskaplike Werk, 47(4). https://doi.org/10.15270/47-4-118

Pollanen, M. (2007). Improving learner motivation with online assignments. Journal of Online Learning and Teaching, 3(2), 203-213.

Provencher, V., Polivy, J., Wintre, M. G., Pratt, M. W., Pancer, S. M., Birnie-Lefcovitch, S., \& Adams, G. R. (2009). Who gains or who loses weight? Psychosocial factors among first-year university students. Physiology \& Behavior, 96(1), 135-141. https://doi.org/10.1016/j.physbeh.2008.09.011

Sevinç, S., \& Gizir, C. A. (2014). Factors Negatively Affecting University Adjustment from the Views of First-Year University Students: The Case of Mersin University. Educational Sciences: theory and practice, 14(4), 1301-1308. https://doi.org/10.12738/estp.2014.4.2081 
Stone, A. (2005). Blended learning, mobility and retention: supporting first-year university students with appropriate technology. In J. Attewell \& C. Savill-Smith (Eds.), Mobile learning anytime everywhere: A book of papers from MLEARN 2004 (pp. 183-185).

Thurber, C. A. \& Walton, E. A. (2012). Homesickness and Adjustment in University Students. Journal of American College Health, 60(5). https://doi.org/10.1080/07448481.2012.673520

Tinto, V. (1993). Leaving college: Rethinking the causes and cures of student attrition (2nd ed.). Chicago, IL: University of Chicago Press. https://doi.org/10.7208/chicago/9780226922461.001.0001

Toquero, C. M. (2020). Challenges and opportunities for higher education amid the COVID-19 pandemic: The Philippine context. Pedagogical Research, 5(4). https://doi.org/10.29333/pr/7947

Van Rooij, E. C., Jansen, E. P., \& van de Grift, W. J. (2018). First-year university students' academic success: the importance of academic adjustment. European Journal of Psychology of Education, 33(4), 749-767. https://doi.org/10.1007/s10212-017-0347-8

Varner, B. (2013). Undergraduate perceptions of online coursework. Journal of Applied Learning Technology, $3(1)$.

Webster, J., \& Watson, R. T. (2002). Analyzing the past to prepare for the future: Writing a literature review. MIS Quarterly, 26(2), 13-23.

Yigit, T., Koyun, A., Yuksel, A. S., \& Cankaya, I. A. (2014). Evaluation of blended learning approach in computer engineering education. Procedia-Social and Behavioral Sciences, 141, 807-812. https://doi.org/10.1016/j.sbspro.2014.05.140

Zaleski, Z. (1996). Future anxiety: Concept, measurement, and preliminary research. Personality and individual differences, 2l(2), 165-174. https://doi.org/10.1016/0191-8869(96)00070-0

\section{Copyrights}

Copyright for this article is retained by the author(s), with first publication rights granted to the journal.

This is an open-access article distributed under the terms and conditions of the Creative Commons Attribution license (http://creativecommons.org/licenses/by/4.0/). 